\title{
Virtual Learning: A New Experience in the Shadow of Coronavirus Disease
}

\author{
Abbas Ebadi (iD ${ }^{1}$ and Esmail Heidaranlu (iD) ${ }^{2, *}$ \\ ${ }^{1}$ Behavioral Sciences Research Center, Life Style Institute, Nursing Faculty, Baqiyatallah University of Medical Sciences, Tehran, Iran \\ ${ }^{2}$ Trauma Research Center, Nursing Faculty, Baqiyatallah University of Medical Sciences, Tehran, Iran \\ "Corresponding author: Trauma Research Center, Nursing Faculty, Baqiyatallah University of Medical Sciences, Tehran, Iran. Email: eheidaranlu@gmail.com
}

Received 2020 July 31; Revised 2020 August 05; Accepted 2020 August 07.

Keywords: Experience, Online Learning, Coronavirus

\section{Dear Editor,}

Distance learning is a type of education in which all or most of the teaching are done through the learner to the learner regardless of time and place, in the sense that all or part of the communication between teachers and learners through one there is artificial media, whether electronic or print (1). By definition, technology is the normal or main tool of communication in distance learning. In fact, distance learning is a guided system or process that connects learners to distant resources. It can also be used as a tool to learn supplements (2). The historical evolution of distance learning has taken place in four main stages (correspondence systems, radio and television education systems, multimedia systems, and Internet systems), each of which, with its organizational form, is one of the main forms of communication has been derived (3).

The history of academic education shows that the University of London (1836), the University of Chicago (1892), and the University of Queensland (1911) were the first educational institutions to establish distance higher education (4). About $95 \%$ of the whole adult formal education is provided in the classroom. Distance e-learning is a phenomenon that arose due to the tendency of learners to have non-face-to-face access to the curriculum, time and place constraints, and the problems of compulsory timely attendance in classrooms (5). For a long time, in most of the educational systems of different countries, teachers have been encouraging students to memorize and repeat scientific concepts by relying on traditional methods, especially lecturing. Despite that in scientific, educational, and even executive circles, there is talk of student activism, intellectual growth, and free-thinking, such views have not been put into practice (6).

In the coronavirus disease pandemic, medical education is no exception to undergo frequent changes that have occurred and continue to occur. Changing education is especially important. The medical education system, like any other management system, has a life, grows and matures, so it needs care and is constantly changing with a certain dynamism. The education system needs comprehensive management and permanent monitoring to maintain the existing quality and is a sustainable quality that is based on constant change and improvement. The issuance of health guidelines for the observance of social distances necessitates a change in the educational needs of students and, consequently, a change in the educational systems (7). The outbreak of the coronavirus disease has affected all political, economic, social, and cultural aspects of the world since early 2020. The coronavirus disease has opened up a strange world to everyone and has had serious side effects. This disease has and will have irreparable consequences in educational spaces due to the accumulation of people. The global crisis caused by the COVID-19 pandemic has also challenged the system of learning, which is routinely based on regular attendance training around the world. What partially alleviates this challenge for the education system is the expansion of virtual media to help the education system. In the face of the coronavirus disease crisis, creating a platform for virtual meetings and distance learning will create a new capacity for student education. Social distancing in most countries, and consequently the closure of schools and universities, has prompted educators to teach in a modern, virtual way and take online exams to prevent the closure of Education. Although the 
prevalence of coronavirus disease in countries has posed problems and difficulties for the education system, it has created an opportunity for new educational strategies to be tested (8).

Education in the coronavirus disease era necessitates a change in students' educational needs and educational systems. Researchers in the field of education consider resistance to change as one of the important reasons for the failure of change in this field. The most important reasons for resisting change in the distance learning during the coronavirus disease pandemic include the lack of trained and skilled manpower, numerous shortcomings in the country's virtual education infrastructure, the sudden attack of COVID-19 and practically not having enough time to prepare for this crisis, insufficient familiarity of professors and students with teaching and interaction in cyberspace, lack of practical commitment of students and professors to active and regular attendance in virtual classes, financial problems and lack of necessary hardware for students, and as the most important factor in medical sciences, the students' lack of learning in practical courses and how to conduct clinical internships (9). Bloomberg recently reported that only $30 \%$ of the 1.5 million population of faculty members in the United States have had virtual teaching experience so far (10). As the available resources for achieving educational goals in universities of medical sciences are limited, measures must be taken to allocate these limited resources to educational goals in the best possible way. One of the most important measures available is the optimal use of cyberspace in continuing education during the coronavirus disease era (11).

It seems that society expects the university both to manage its own crisis and to help manage the crisis throughout the country. Among the most important concerns of faculty members and students in the coronavirus disease epidemic are the inability in the provision of practical courses and internships, performing the exams, and the possibility of cheating in cyberspace, the traditional resistance to change towards virtual education, and the reduction of effective social interactions. Education experts believe that education can be kept alive without a physical presence. To be able to implement education in medical universities in the era of the coronavirus disease crisis, electronic and Internet infrastructures need to be completed quickly, and university officials should take steps to empower faculty members and students to take advantage of this opportunity.

\section{Footnotes}

Authors' Contribution: EH and AE have worked together and did concept and design and all study phases.

Conflict of Interests: The authors of the article state that there is no conflict of interest.

Ethical Approval: The mentioned research with the code IR.BMSU.REC.1399.150 has been approved by the Ethics Committee of the Ministry of Health.

Funding/Support: The authors of the article declare that they are not funded from anywhere.

\section{References}

1. Setiawan AR. Scientific Literacy Worksheets for Distance Learning in the Topic of Coronavirus 2019 (COVID-19). Edarxiv. 2020.

2. Azar A, Khamis AH, Naidoo N, Lindsbro M, Gonuguntla S, Banerjee Y. Creating a 'simulacrum'of in-class learning environment employing distance learning modality during the COVID-19 pandemia: Quod Erat Demonstrandum. BMC Med Educ. 2020.

3. Clark JT. Distance education. Clinical Engineering Handbook. Elsevier; 2020. p. 410-5.

4. Anarinejad A, Mohammadi M. The practical indicators for evaluation of e-learning in higher education in Iran. Interdisciplinary Journal of Virtual Learning in Medical Sciences. 2020;5(1):11-25.

5. Rueda L, Benitez J, Braojos J. From traditional education technologies to student satisfaction in Management education: A theory of the role of social media applications. Information $\&$ Management. 2017;54(8):1059-71

6. Khoshnoodifar M, Rafie S, Zeraati Nasrabadi M, Masoudi Alavi N. The Effects of CPR Training Using Two Traditional and Electronic Training Methods on the Knowledge, Skill, and Satisfaction of Nurses from In Service Education of Cardiopulmonary Resuscitation. Qom University of Medical Sciences Journal. 2019;13(9):34-43.

7. Viner RM, Russell SJ, Croker H, Packer J, Ward J, Stansfield C, et al. School closure and management practices during coronavirus outbreaks including COVID-19: a rapid systematic review. The Lancet Child \& Adolescent Health. 2020.

8. Tzifopoulos M. In the shadow of Coronavirus: Distance education and digital literacy skills in Greece. International Journal of Social Science and Technology. 2020;5(2):1-14.

9. Raoofi A, Takian A, Sari AA, Olyaeemanesh A, Haghighi H, Aarabi M. COVID-19 pandemic and comparative health policy learning in Iran Archives of Iranian Medicine. 2020;23(4):220-34.

10. Pisano GP, Sadun R, Zanini M. Lessons from Italy's response to coronavirus. Harvard Bus Rev. 2020.

11. Zaharah Z, Kirilova GI. Impact of Corona Virus Outbreak Towards Teaching and Learning Activities in Indonesia. SALAM: Jurnal Sosia dan Budaya Syar-i.2020;7(3). 